\title{
Synthesis and Characterisation of a New Hydrophilic Interaction/Reversed Phase Mixed-Mode Chromatographic Stationary Phase
}

\author{
Yeni bir Hidrofilik Etkileşim/Ters Faz Karışık-Mod Sıvı \\ Kromatografik Sabit Fazın Sentezi ve Karakterizasyonu
}

\author{
Research Article
}

Hayriye Aral*

University of Batman, Faculty of Science and Art, Department of Chemistry, Batman, Turkey.

\section{A B S TR AC T}

\begin{abstract}
$\Lambda$ novel multifunctional stationary phase based the amide-silica was synthesised starting from L-isoleucine A and 2-aminoacetanilide. Hereby, compounds 1, 2, 3 and 4 were synthesised for the first time and 1, 2 and 4 were identified. The stationary phase was synthesised by a reliable and repeatable method and characterized by elemental analysis, solid state 13C NMR, scanning electron microscope (SEM), and Brunauer, Emmett and Teller (BET). This stationary phase possess four amide groups as polar cites, phenyl ring as aromatic non-polar cite and isopropyl as an aliphatic non-polar cite. Therefore, it can act as both hydrophilic interaction (HILIC) and reversed phase (RPLC) chromatographic stationary phase. The stationary phase has also chirality and can be used in enantioseparation of racemic compounds in normal phase chromatography (NPLC).
\end{abstract}

\section{Key Words}

Mixed-mode stationary phase, Hydrophilic interaction liquid chromatography (HILIC), Isoleucine, Chiral stationary phase.

\section{öz}

-izolözin ve 2-aminoasetanilitten yola çıkılarak amid-silika tabanlı çok fonksiyonlu yeni bir dolgu _ maddesi sentezlendi. Bu vesile ile bileşik 1, 2, 3 ve 4 ilk kez sentezlenmiş olup bileşik 1, 2 ve 4'ün ayrıntılı karakterizasyonları yapılmıştır. Dolgu maddesi güvenilir ve tekrarlanabilir bir yöntemle sentezlenmiş olup yapısı katı faz ${ }^{13} \mathrm{C}$ NMR, taramalı elektron mikroskobisi (SEM), ve Brunauer, Emmett and Teller (BET) ile doğrulandı. Yeni geliştirilen bu dolgu maddesi polar grup olarak dört amid grubu, apolar gruplar olarak da aromatik halka ve alifatik zincir içerir. Bu nedenle, bu dolgu maddesi hem hidrofilik etkileşim (HILIC) hem de ters faz (RPLC) sıvı kromatografisinde kullanılabilir. Dolgu maddesinin L-izolözinden sentezlendiği için aynı zamanda kiraldir ve normal faz kromatografide rasemik bileşiklerin enantiyomerik ayrılmasında kullanılabilir.

\section{Anahtar Kelimeler}

karışık-mod dolgu maddesi, hidrofilik etkileşik sıvı kromatografisi (HILIC), izolözin, kiral dolgu maddesi (CSP).

Article History: Received: Oct 21, 2017; Revised: May 18, 2017; Accepted: Feb 02, 2017; Available Online: Feb $20,2018$. DOI: $10.15671 /$ HJBC.2018.213

Correspondence to: H. Aral, University of Batman, Faculty of Science and Art, Department of Chemistry, Batman, Turkey. 


\section{INTRODUCTION}

The most important element of the chromatography is the stationary phase. The structure of the stationary phase affects the retention mechanisms, separation selectivity, and column efficiency [1]. Most stationary phases only provided single separation mechanism [2-6] and were applied in single chromatographic mode. A recent trend in HPLC involves the development of new multifunctional stationary phases having polar and nonpolar groups for separations of wide range of analytes classes from polar to nonpolar [7-13]. This type of stationary phase refered as "mixed-mode" [14].

The mixed mode approach has emerged because of the need for better retention control for both polar and non-polar molecules [15-19]. Multiple mechanisms of interactions allow the use of one stationary phase for a much wider range of applications as compared to RP or HILIC approach. At least two interactions between the anlytes and the stationary phase should be present in the mixed-mode mechanism [20]. Thus, simultaneous separation of polar and non-polar, ionisable and neutral and other complex mixtures is possible and the cost of analysing can be reduced using this kind of stationary phase. Several kind of stationary phases with mixed-mode performance have been investigated such as phenylpropanolamine [10], phenylamine [7,21,22], 8-quinolinol [24], poly(1allylimidazole) [25], imidazole [26,27], pyridine $[28,29]$ and dipyridine [30] functional silicas. In recent years, the mixed-mode chromatography has been shown to be a versatile approach for the simultaneous separation of highly mixed classes of analytes from polar to nonpolar organic compounds $[31,32]$.

Subsequently, polar stationary phases have exhibited novel properties for polar analytes [33]. Recent investigations describing stationary phases containing polar groups have shown the superior performance of these new phases over conventional RPLC stationary phase complex analytes [33,34]. The polar groups, particularly amide, were originally chosen for their ability to interact with both alkaline and acidic analytes $[16,19]$.

RPLC is the mostused HPLC mode for separation of moderately polar and weakly polar analytes, while HILIC is often used to separate strongly polar compounds. Thus, mixed-mode RPLC/HILIC can be used for the separation of both polar and nonpolar analytes, overcoming the deficiencies of RPLC and HILIC [35-50]. There is a continual increase in research in this area to find an ideal stationary phase and to investigate mixed-mode separation mechanisms.

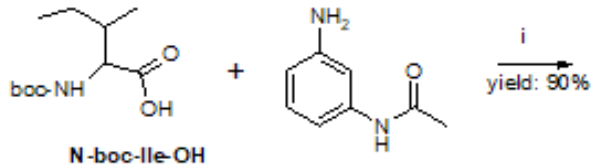

$\mathrm{N}$-boc-lle- $\mathrm{OH}$<smiles>CCC(C)C(NC(=O)C(=O)NCCCOC)C(=O)Nc1cccc(NC(C)=O)c1</smiles>

4<smiles>CCC(C)C(NC(=O)C(=O)NCCC[Si]12OCCC(CO1)O2)C(=O)Nc1cccc(NC(C)=O)c1</smiles>
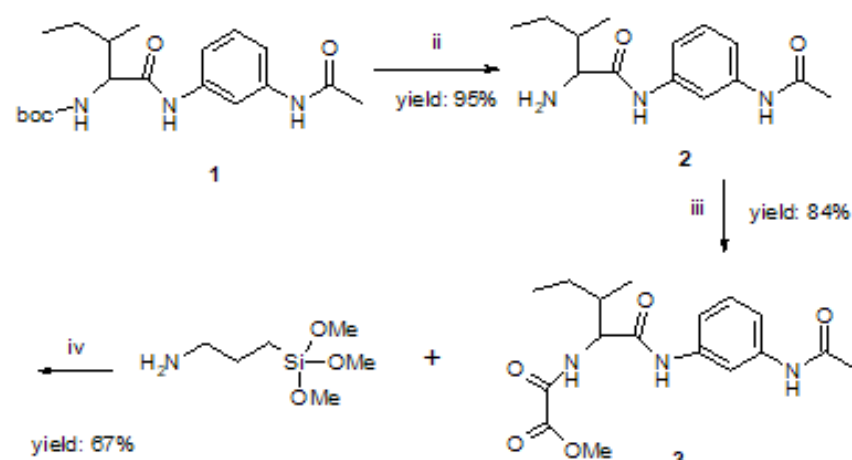<smiles>CCC(C)C(NC(=O)C(=O)OC)C(=O)Nc1cccc(NC(C)=O)c1</smiles>

Figure 1. Synthesis of the new amide compounds and ile-AA-mix stationary phase. 
In this study, a novel amide-functionalised silica-based multifunctional stationary phase was prepared starting from 3-aminoacetanilide and L-isoleucine as starting materials (Figure 1). The developed stationary phase possesses four amide groups as polar sites, as well as hydrophobic chain and an aromatic ring as nonpolar sites. Hence, this new stationary phase possesses both HILIC and RPLC dual retention mechanisms and should be successfully used for separation of different group of polar and nonpolar compounds.

\section{MATERIALS and METHODS}

\section{Reagents and Materials}

Spherical silica gel (Lichrospher Si 60, $5 \mu \mathrm{m}$, $60 \AA, 700 \mathrm{~m}^{2} \mathrm{~g}^{-1}$ ) was purchased from Merck. All of the reagents and solvents were purchased from Sigma-Aldrich or Merck. All of the reagents used in the synthesis were of "reagent grade" unless otherwise specified. The IR spectra were recorded on a Mattson 1000 FTIR spectrometer. Elemental analyses were performed with a Thermo Scientific FLASH 2000 instrument. Deionized water was purified using a Millipore Milli-Q water system. SEM images were obtained using a LEO EVO 40 model instrument (İnönü University, SEM Laboratory). Solid state ${ }^{13} \mathrm{C}$ NMR was recorded using a Bruker Superconducting FT.NMR Spectrometer Avance TM 300 MHz WB instrument (Middle East Technical University, Central laboratory, Solid state NMR laboratory). ${ }^{1} \mathrm{H}(400 \mathrm{MHz})$ and ${ }^{13} \mathrm{C}(100 \mathrm{MHz})$ NMR spectra were recorded on a Bruker DPX-400 High Performance Digital FT-NMR Spectrometer (Dicle University, Faculty of Science, NMR Laboratory). Textural characteristics were determined by nitrogen adsorption at $67 \mathrm{~K}$ with an automatic adsorption instrument (Micromeritics, ASAP 2020) and the BET surface area $\left(\mathrm{S}_{\mathrm{BET}}\right)$, total pore volume $\left(\mathrm{V}_{\mathrm{T}}\right)$ and poresize distribution were determined from nitrogen adsorption-desorption data by using

Table 1. Properties of the lle-AA-Mix column.

\begin{tabular}{|c|c|}
\hline Limit pressure & 500 bar \\
\hline${ }^{1}$ Max. flow rate for $100 \% \mathrm{EtOH}$ & $1.8 \mathrm{ml} / \mathrm{min}$ \\
\hline${ }^{1}$ Max flow rate for EtOH/water: 50/50 & $1.2 \mathrm{ml} / \mathrm{min}$ \\
\hline${ }^{1}$ Max flow rate for $100 \%$ water & $2.5 \mathrm{ml} / \mathrm{min}$ \\
\hline${ }^{1}$ Max flow rate for Water/ACN: 50/50 & $3.1 \mathrm{ml} / \mathrm{min}$ \\
\hline${ }^{1}$ Max flow rate for $100 \%$ ACN & $5 \mathrm{ml} / \mathrm{min}$ (320 bar) \\
\hline${ }^{2}$ Extent of labelling & $13.74 \%$ carbon loading \\
\hline L x I.D. & $250 \mathrm{~cm} \times 4.6 \mathrm{~mm}$ \\
\hline Surface coverage & $0.50 \mathrm{mmol} / \mathrm{gr}$ \\
\hline Matrix active group & Amide, phenyl, alkyl \\
\hline${ }^{3}$ Particle size & $5 \mu \mathrm{m}$ \\
\hline${ }^{3}$ Pore size & $60 \AA$ \\
\hline${ }^{4}$ Surface area & $659 \mathrm{~m}^{2} \mathrm{~g}^{-1}$ \\
\hline${ }^{4}$ Total pore volume & $0.66 \mathrm{~cm}^{3} \mathrm{~g}^{-1}$ \\
\hline Operation $\mathrm{pH}$ range & $2.5-9.00$ \\
\hline
\end{tabular}

${ }^{1}$ Max. flow rate was determined at the maximum operation pressure (500 bar) and $20^{\circ} \mathrm{C}$ temperature.

${ }^{2}$ Based on the elemental analysis.

${ }^{3}$ Based on the information given by the company of the blank silica.

${ }^{4}$ Based on the BET analysis. 
Quantachrome software (Dicle University, Central Research Laboratory, DÜBTAM).

\section{Packing of Chromatographic Column}

An empty stainless steel HPLC column (250x4.6 $\mathrm{mm}$ ) was packed with an Ile-AA-Mix using the slurry packing technique under 500 bar pressure. Approximately $3.5 \mathrm{~g}$ of the stationary phase was used to prepare the column. Ethanol (EtOH) was used as the packing solvent. A total of $4 \mathrm{gr} l l e-$ $\mathrm{AA}-\mathrm{Mix}$ was dispersed into $\mathrm{EtOH}$ and sonicated in the ultrasonic bath for 5 minutes, after which the slurry was packed into the empty column under a constant pressure of 500 bar. Lastly, the prepared columns were rinsed for $5 \mathrm{~h}$ with $\mathrm{EtOH}$ $1 \mathrm{~h}$ with $\mathrm{EtOH} /$ water (50:50), $1 \mathrm{~h}$ with water, $1 \mathrm{~h}$ with water:ACN (50:50) and $1 \mathrm{~h}$ with $A C N$, respectively, as the eluents at $1 \mathrm{~mL} / \mathrm{min}$. Several properties of the new Ile-AA-Mix column are given in Table 1.

\section{Synthesis of Compound 1}

Dicyclohexylcarbodiimide (DCC, $3.03 \mathrm{~g}, 14.7$ mmol) dissolved in $\mathrm{CH}_{2} \mathrm{Cl}_{2}(10 \mathrm{~mL})$ was added to a stirred solution of $\mathrm{N}$-Boc-isoleucine $(3.05 \mathrm{~g}, 13.4$ $\mathrm{mmol})$, 4-phenylbutylamine $(2.10 \mathrm{~g}, 13.4 \mathrm{mmol})$ and HOBT $(2.18 \mathrm{~g}, 16.1 \mathrm{mmol})$ in $\mathrm{CH}_{2} \mathrm{Cl}_{2}(200 \mathrm{~mL})$ at $\mathrm{O}^{\circ} \mathrm{C}$. After stirring for $24 \mathrm{~h}$ at room temperature, the mixture was filtered and extracted with $1 \mathrm{~N}$ $\mathrm{HCl}(100 \mathrm{X} 2 \mathrm{~mL}), 5 \% \mathrm{NaHCO}_{3}(10 \mathrm{~mL})$ and water $(10 \mathrm{~mL})$ respectively. The extract was dried over $\mathrm{Na}_{2} \mathrm{SO}_{4}$, filtered and evaporated under reduced pressure to afford a pure N-boc-ile-AA as a white solid.(TLC: $\mathrm{Rf}=0.32$ with $\mathrm{H}:$ EtOAC = 3:1). Yield: 4.70 g, 99\%. Mp: $158-159^{\circ} \mathrm{C}$. IR $\left(\mathrm{cm}^{-1}\right) ; 3335$ and 3309 (Amide $\mathrm{N}-\mathrm{H}$ ), 3201 (carbamate $\mathrm{N}-\mathrm{H}$ ), 3063 (Ar-H), 1679 (carbamate $\mathrm{C}=0$ ), 1665 (amide $\mathrm{C}=0$ ), 1612 (amide $\mathrm{C}=\mathrm{O}$ ), 1310 (carbamate $\mathrm{C}-\mathrm{O}-\mathrm{C}$ ), 1240 (carbamate $\mathrm{C}-\mathrm{N}-\mathrm{C}$ ), 1170 (amide $\mathrm{C}-\mathrm{N}-\mathrm{C}$ ). ${ }^{1} \mathrm{H}$ NMR $\left(\mathrm{CDCl}_{3}\right): \delta(\mathrm{ppm}) ; 0.89(\mathrm{t}, 3 \mathrm{H}), 0.98(\mathrm{~d}, 3 \mathrm{H}), 1.10-$ $1.30(\mathrm{~m}, 1 \mathrm{H}), 1.44(\mathrm{~s}, 9 \mathrm{H}), 1.50-1.70(\mathrm{~m}, 1 \mathrm{H}), 1.80-$ $2.00(\mathrm{~m}, 1 \mathrm{H}), 2.01(\mathrm{~s}, 3 \mathrm{H}), 4.17(\mathrm{~s}, 1 \mathrm{H}), 5.52(\mathrm{~d}, 1 \mathrm{H})$, 7.11-7.19 (m, 2H), $7.34(\mathrm{~m}, 1 \mathrm{H}), 7.53(\mathrm{~m}, 1 \mathrm{H}), 8.07$ $(\mathrm{s}, 1 \mathrm{H}), 8.91(\mathrm{~s}, 1 \mathrm{H}) .{ }^{13} \mathrm{C}$ NMR $\left(\mathrm{CDCl}_{3}\right)$ : (ppm); 11.12, $15.57,24.38,24.89,28.35,37.20,60.12,80.27$, $11.87,115.88,116.30,129.19,138.03,138.43,156.44$ $169.06,171.09$.

\section{Removal of the boc-Group to Obtain Compound 2}

TFA/AcOH (1:1) (14 mL) was added to a stirred solution of $1(3.0 \mathrm{~g}, 8.3 \mathrm{mmol})$ in $\mathrm{CH}_{2} \mathrm{Cl}_{2}(30 \mathrm{~mL})$ at $\mathrm{O}^{\circ} \mathrm{C}$. After stirring $24 \mathrm{~h}$ at room temperature, the solvent was evaporated and the $\mathrm{pH}$ was adjusted to $9-10$ by adding $1 \mathrm{~N} \mathrm{KOH}$ to the residue. The mixture was extracted with $\mathrm{CH}_{2} \mathrm{Cl}_{2}(30 \mathrm{~mL} \times 3), 0.1$ $\mathrm{N} \mathrm{HCl}(10 \mathrm{~mL})$ and water $(30 \mathrm{mLx} 2)$, respectively, and dried over $\mathrm{Na}_{2} \mathrm{SO}_{4}$, filtered and evaporated under reduced pressure to afford a pure 2 as a viscous oil (monitoring by TLC). $R_{f}=0$ with $\mathrm{H}$ :EtOAC $=3: 1, R_{f}=0.25$ with $\mathrm{H}:$ EtOAc/TEA $=1: 2: 0.2$. Yield: $2.05 \mathrm{~g}, 99 \%$.

\section{Synthesis of Compound 3}

A solution of dimethyloxalate $(18.24 \mathrm{mmol}, 2.06$ $\mathrm{g}$ ) in $\mathrm{MeOH}(15 \mathrm{~mL})$ was added to the lle-AA (8.5 mmol, $2.13 \mathrm{~g}$ ) dissolved in $\mathrm{MeOH}(20 \mathrm{~mL})$. After stirring for $24 \mathrm{~h}$ at room temperature under an argon atmosphere, the solvent was evaporated and the residue was purified by column chromatography on silica gel (PE:EtOAc $=2: 1)$ to afford 3 as a white solid. Yield: $2.29 \mathrm{~g}, 80 \%$. Mp: 168-169. IR $v\left(\mathrm{~cm}^{-1}\right) ; 3275$ (sb, H-N of two amides), 3074 ( Ar-H), 3042 (Ar-H), 1754 (C=O, ester), 1656 ( $\mathrm{NH}$, amide), 1619 ( $\mathrm{NH}$, amide), 1209 (C-O-C, ester), 1175 (C-N-C, amide), 1175 (C-N-C, amide). ${ }^{1} \mathrm{H}$ NMR $\left(\mathrm{CDCl}_{3}\right): \delta(\mathrm{ppm}) ; 0.83-1.00(\mathrm{~m}, 6 \mathrm{H}), 1.10-1.27(\mathrm{~m}$, $1 \mathrm{H}), 1.45-1.68(\mathrm{~m}, 1 \mathrm{H}), 1.90-2.11(\mathrm{~m}, 1 \mathrm{H}), 2.15(\mathrm{~s}, 3 \mathrm{H})$, $3.89(\mathrm{~s}, 3 \mathrm{H}), 4.59(\mathrm{~d}, 1 \mathrm{H}), 7.14-7.40(\mathrm{~m}, 3 \mathrm{H}), 7.71(\mathrm{~s}$, $1 \mathrm{H}), 8.03(\mathrm{~d}, 1 \mathrm{H}), 8.27(\mathrm{~s}, 1 \mathrm{H}), 9.27(\mathrm{~s}, 1 \mathrm{H}){ }^{13} \mathrm{C} N M R$ $\left(\mathrm{CDCl}_{3}\right): \delta(\mathrm{ppm}) ; 11.08,15.38,24.37,24.79,37.81$, 53.76, 59.30, 112.19, 116.30, 116.50, 129.31, 137.97, $138.46,156.61,160.61,169.14,169.46$.

\section{Preparation of the Stationary Phase (4 and Ile-AA-Mix)}

The mixture of $3(1 \mathrm{~g}, 3 \mathrm{mmol})$ and 3 -amino propyltrimethoxysilane $(0.50 \mathrm{~g}, 2.8 \mathrm{mmol})$ dissolved in $\mathrm{MeOH}(30 \mathrm{~mL}$ ) was stirred at room temperature for $24 \mathrm{~h}$. The mixture was cooled to $+4^{\circ} \mathrm{C}$ and the white precipitate was washed with cold $\mathrm{MeOH}$, filtered and evaporated to afford $1.2 \mathrm{~g}$ of 5. Yield: $80 \%$. Mp: decomposition, 230$250^{\circ} \mathrm{C}$. (IR spectrum was given in Supplementary Materials as Figure S7). Next, $0.4 \mathrm{~g}$ of the 5 was dissolved in a mixture of toluene $(30 \mathrm{~mL})$ and DMSO $(10 \mathrm{~mL})$ at $130^{\circ} \mathrm{C}$. Spherical silica gel (2 gr) was added to the mixture. After stirring at $130^{\circ} \mathrm{C}$ for $48 \mathrm{~h}$, the mixture was filtered and the new silica material was washed with toluene $(10 \mathrm{~mL})$, $\mathrm{CHCl}_{3}(20 \mathrm{~mL})$, ETOH $(20 \mathrm{~mL})$, EtOH:EtOAc $(1: 1,20$ $\mathrm{mL}$ ) and acetone (30 $\mathrm{mL})$, respectively. The white powders were dried on a rotary evaporator device at $90^{\circ} \mathrm{C}$ under reduced pressure for a total of 20 $\mathrm{h}$ to afford Ile-PBA-Mix as a new stationary phase. 
Elemental analysis: C 13.74, H 2.29, N 2.05 (0.50 $\mathrm{mmol}$ of loaded ligand/g SP. The characterizations of the new phase are given in the next sections.

\section{RESULTS and DISCUSSION}

\section{Synthesis}

The synthesis of the new multifunctional stationary phase based on the amidefunctionalised silica gel is outlined in Figure 1. This stationary phase includes four amide groups as polar sites; and aliphatic and aromatic groups as nonpolar sites. Therefore, it is expected that the Ile-AA-Mix stationary phase can well interact with polar, moderately polar, weakly polar and non-polar compounds to separate complex mixture under HILIC and RPLC condition. In addition, the Ile-AAMix stationary phase has two stereogenic centres. Thus, it can act as chiral stationary phase for enantioseparation of several racemic mixtures in NPLC mode.

The new stationary phase was synthesised in five steps. First, compound 1 was obtained in $92 \%$ yield by the reaction of $\mathrm{N}$-boc-isoleucine with 3-aminoacetanilid without applying any other purification technique. The deprotection of 1 gave a pure 2 in 99\% yields after only with work-up, without any further purification. The reaction of 2 with two equivalents of dimethyl oxalate gave 3 in $80 \%$ yields. The 3 was reacted with 3-aminopropyltrimethoxysilane to obtain 4 in $67 \%$ yield. This final ligand was attached to the HPLC-quality spherical silica gel to obtain ile-AAMix as a novel mixed-mode stationary phase.

Commonly, two main methods have been reported for preparing a chromatographic stationary phase by functionalization of silica particles. The first method is that a silica modified with any of propyltrimethoxysilane (amino- or chloropropyltrimethoxysilanes). Then, the new organic ligands are directly grafted onto the surface of silica. Due to the not required any isolation, purification and identification process in the last two steps, this method is relatively simple [1] but has several serious disadvantages. The most important of these issues is low reproducibility because the controllability of a reaction on a solid phase is quite difficult. Often, all of the amino- or chloro- groups on the propylated silica surface are not replaced with the organically functionalised ligand. This phenomenon leads to low reproducibility of the stationary phase. Hence, the more reactions performed on the solid phase, the lower the reliability.

The second method is that the organically functionalised reagents are first treated with terminally functionalised propyltrimethoxysilane to form trimethoxysilyl-terminated organically functionalised reagents. Then, the new organically functionalised reagents could be directly bonded to the surface of silica [29]. Purification and isolation are needed for all steps and it is difficult to select suitable solvents in the subsequent steps, thus this method is more difficult than first method [1] but is more reliable because there is only a one-step reaction on silica. Thus, controllability and reproducibility are very high. Therefore, we preferred the second, more reliable method. Although the five step synthesis appears to be long and disadvantageous, the high yields of each step, the simplicity of the synthesis procedures and the high reproducibility of the stationary phase make this synthesis process very attractive and reliable.

In a most recent article, a "solventfree" and green method for controllable and quantitative preparation of chromatographic stationary phase was proposed by Liu and co-authors [46]. In this study, the mixture of 3-chloropropyltrimethoxysilane, silica and excessive $\mathrm{N}$-methylimidazolium were stirred at $120^{\circ} \mathrm{C}$ for $48 \mathrm{~h}$ to obtain the new stationary phase with quantitative yield in one step. Synthesis of a stationary phase in one step and solvent free is very attractive.

\section{Characterization of the Stationary Phase}

The stationary phase was synthesized in three separate parts simultaneously to evaluate the reproducibility of the synthesis process, under the same conditions, and using the same amounts of materials. These were named part 1 , part 2 and part 3. Elemental compositions were measured for the three parts. As shown in Table 2, the nitrogen contents of each of the three parts of the lle-AAMix were 2.10, 2.04 and 2.01, respectively. There is no significant difference between the three parts. The surface concentration of the Ile-PBAMix stationary phase was estimated to be 0.50 mmol g-1, which was calculated from the average 
Table 2. Elemental Analysis results of blank silica and three part of Ile-AA-Mix.

\begin{tabular}{llll}
\hline Elemental analysis results & $\mathrm{C}$ & $\mathrm{H}$ & $\mathrm{N}$ \\
\hline Blank Silica & $(\%)$ & $(\%)$ & $(\%)$ \\
\hline Ile-PBA-Mix Part-1 & 0 & 0.04 & 0 \\
\hline Ile-PBA-Mix Part-2 & 13.84 & 2.38 & 2.10 \\
\hline Ile-PBA-Mix Part-3 & 13.77 & 2.22 & 2.04 \\
\hline Average & 13.65 & 2.27 & 2.01 \\
\hline
\end{tabular}

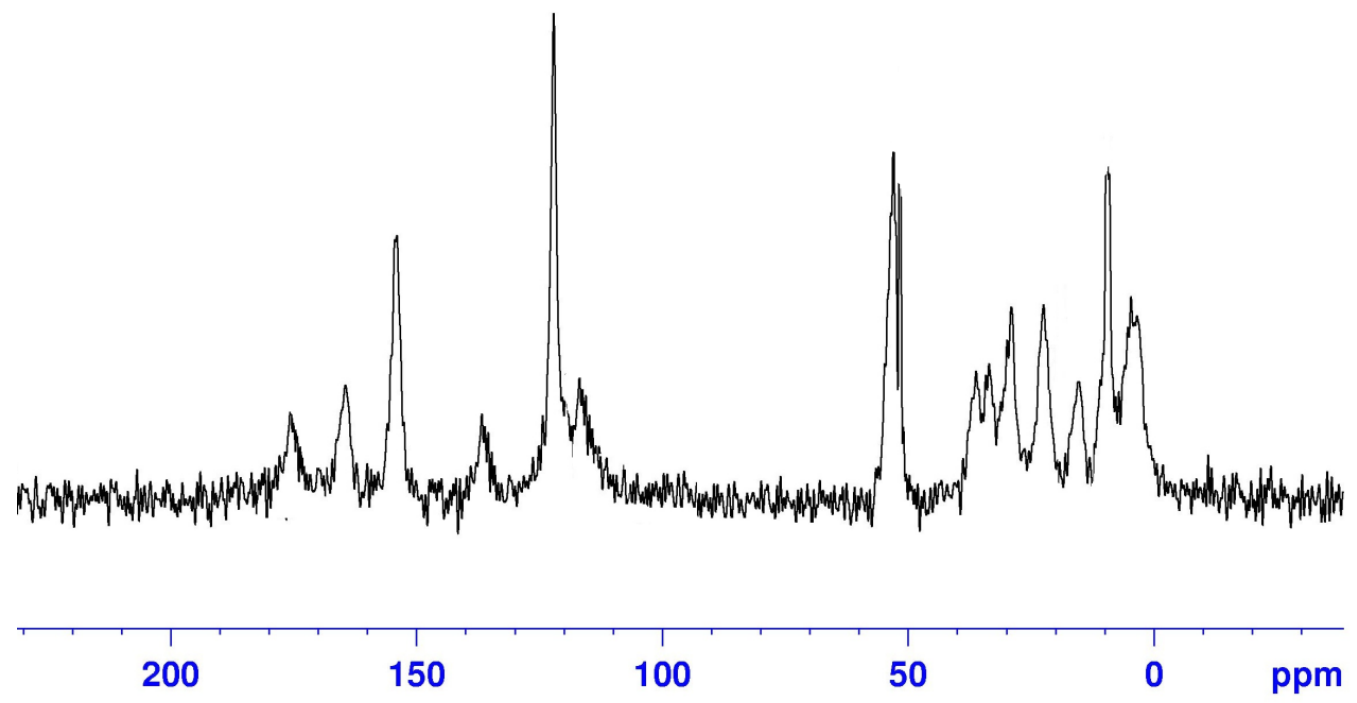

Figure 2. Solid state ${ }^{13} \mathrm{C}$ NMR spectrum of Ile-AA-Mix stationary phase.

nitrogen content. The elemental compositions of the three parts of the lle-AA-Mix were very close, showing that the reproducibility of the synthesis process is very high.

The Ile-AA-Mix was characterized by solid state ${ }^{13} \mathrm{C}$ NMR (Figure 2). The signal at $150-180$ ppm was assigned to the carbon atoms of the carbonyl groups and at 110-140 ppm was assigned to aromatic carbon atoms of the ligand bonded to surface of silica. The resonances between 0-40 ppm were assigned to the aliphatic carbon atoms of methyl $\left(\mathrm{CH}_{3}\right)$ and methylene $\left(\mathrm{CH}_{2}\right)$. The signals around $50 \mathrm{ppm}$ was assigned to methane $(\mathrm{CH})$ carbons. The IR and NMR results clearly confirmed that the original organic ligand was definitely bonded to the silica surface.
The specific surface area and the total pore volume of the Ile-AA-Mix material measured by the nitrogen adsorption method using BET analysis were calculated to be $659 \mathrm{~m}^{2} \mathrm{~g}^{-1}, 0.66$ $\mathrm{cm}^{3} \mathrm{~g}^{-1}$ respectively, which are greatly reduced compared to those of the blank silica $\left(799 \mathrm{~m}^{2} \mathrm{~g}^{-1}\right.$, $0.79 \mathrm{~cm}^{3} \mathrm{~g}^{-1}$ )

The stationary phase was also identified by SEM to observe if there is a change in particle shape and size of the spherical silica gel after modification. The comparison of the SEM spectra of blank silica gel and that of the Ile-AA-Mix stationary phase showed a narrow particle size distribution and the same geometry with welldefined spherical particles (Figure 3). 


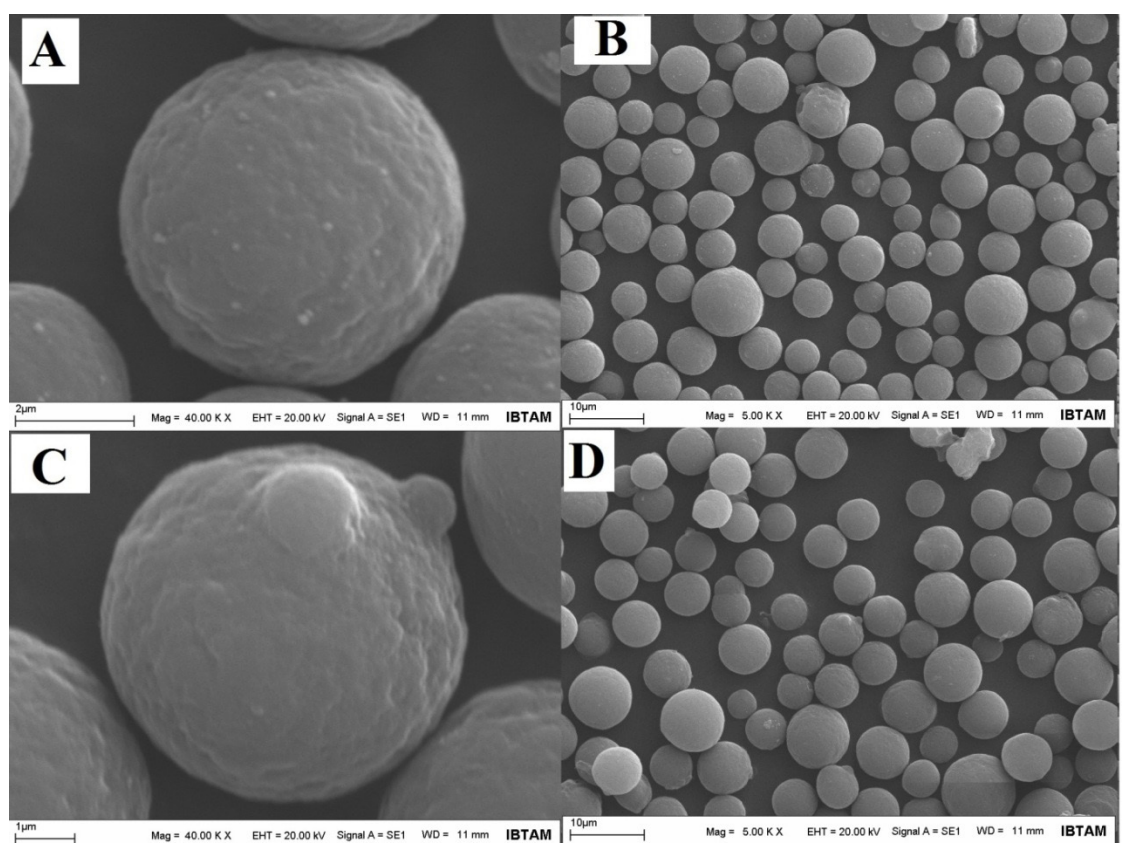

Figure 3. SEM image of blank silica (A) and the Ile-AA-Mix (B).

As a result, four new compounds derived from L-isoleucine were synthesized as a first time and structure of the compound 1 and 3 were identified by $I R,{ }^{1} \mathrm{H}$ NMR and ${ }^{13} \mathrm{C}$ NMR and of compound 4 were identified by IR. The new stationary phase Ile-AA-Mix was characterised by elemental analysis and solid state ${ }^{13} \mathrm{C}$ NMR, BET and SEM measurements and the successful derivatization was confirmed.

\section{Column Stability Tests}

The stability tests for the Ile-AA-Mix column were achieved in the $\mathrm{pH}$ 2.50-9.00 range using two newly prepared and previously unused 50x4.6 $\mathrm{mm}$ columns filled with lle-AA-Mix stationary phase. The chromatographic conditions for the tests were as follows: mobile phase for low $\mathrm{pH}$ values: $100 \%$ of $40 \mathrm{mM}, \mathrm{pH}=2.50$ aqueous ammonium formate and for high $\mathrm{pH}$ : $100 \%$ of $40 \mathrm{mM}, \mathrm{pH}=9.00$ aqueous ammonium chloride buffer; flow rate, $1 \mathrm{~mL} / \mathrm{min}$; temperature, $60^{\circ} \mathrm{C}$; detection, $280 \mathrm{~nm}$; probe, uracil and aniline.

The column was continuously purged with the mobile phase with 2.50 of $\mathrm{pH}$ and was periodically tested by recording the retention time of uracil and aniline. After approximately 4000 column volumes of mobile phase with a 3.0 of $\mathrm{pH}$ were purged through the column, there was essentially no change in the retention times for uracil and aniline (below 2\%). When 2000 volumes of mobile phase with 2.5 of $\mathrm{pH}$ passed through the column, there was essentially no change in the retention times for uracil and aniline, while 5-10\% change was observed after 4000 column volumes of mobile phase. Therefore, we found that the column is highly stable at 2.50 of $\mathrm{pH}$.

The same experiments were repeated for 9.00 of $\mathrm{pH}$ conditions using another unused $50 \times 4.6 \mathrm{~mm}$ column filled with Ile-AA-Mix stationary phase. After approximately 2000 column volumes of mobile phase with 9.00 of $\mathrm{pH}$, the changes in the retention for probes are below $2 \%$. However, after 3000 volumes, there was just approximately $3-5 \%$ change and after 4000 volumes approximately $10 \%$ change in the retention time of adenine and aniline. Hence, although the column is quite stable at 9.00 of $\mathrm{pH}$, it is important to be careful working above $\mathrm{pH} 9$. As a result, this column is very stable between 2.5 and 9 of $\mathrm{pH}$ values.

\section{CONCLUSION}

A new multifunctional mixed-mode chromatographic stationary phase was prepared by modification of spherical silica gel by five steps. Four new amide compounds and a new 
mixed-model chromatographic stationary phase derived from L-isoleucine were synthesised as a first time. The structure of three compounds has been identified and the new stationary phase has been well characterized by many different spectroscopic techniques. The high yields of each step, the simplicity of the synthesis procedures and the high reproducibility of the stationary phase make this synthesis process very attractive and reliable. Future work will be take advantage of this stationary phase to separate very complex analytes composed of very polar or nonpolar compounds.

\section{ACKNOWLEDGEMENT}

The authors gratefully acknowledge the financial support provided by the Research Project Council of Batman University (BTÜBAP) (Project No: BTÜBAP-2012-FED-03). In addition, the authors thanks to Dr. Mehmet Çolak for recording the ${ }^{1} \mathrm{H}$ and ${ }^{13} \mathrm{C}$ NMR spectra of all compounds.

\section{References}

1. L. Zhang, Q. Dai, X. Qiao, C. Yu, X. Qin, H. Yan, Mixed-mode chromatographic stationary phases: Recent advancement and its aplications for highperformance liquid chromatography, Trends Anal. Chem., 82 (2016) 143-163.

2. P. Janas, S. Bocian, P. Jandera, T. Kowalkowski, B. Buszewski, Separation of flavonoids on different phenyl-bonded stationary phases-the influence of polar groups in stationary phase structure, J. Chromatogr. A, 1429 (2016) 198-206.

3. Y. Liu, Z. Guo, Y. Jin, X. Xue, Q. Xu, F. Zhang, et al., Click oligo(ethylene glycol)": an excellent orthogonal stationary phase to $\mathrm{C} 18$ for twodimensional reversedphase/ reversed-phase liquid chromatography, J. Chromatogr. A, 1206 (2008) 153159.

4. P. Jandera, Z. Kučerova, J. Urban, Retention times and bandwidths in reversedphase gradient liquid chromatography of peptides and proteins, J. Chromatogr. A, 1218 (2011) 8874-8889.

5. X. Guo, X. Zhang, Z. Guo, Y. Liu, A. Shen, G. Jin, et al., Hydrophilic interaction chromatography for selective separation of isomeric saponins, J. Chromatogr. A, 1325 (2014) 121-128.

6. P. Jiang, D.Wu, C.A. Lucy, Determination of void volume in normal phase liquid chromatography, J. Chromatogr. A, 1324 (2014) 63-70.

7. A.J. Alpert, M. Shukla, A.K. Shukla, L.R. Zieske, S.W. Yuen, M.A.J. Ferguson, A. Mehlert, M. Pauly, R. Orlando, Hydrophilic-interaction chromatography of complex carbohydrates, J. Chromatogr. A, 676 (1994) 191-202
8. A.J. Alpert, Advances in Chromatography, 44 (2006) 317-329.

9. M. R. Gama, R. G. C. Silva, C. H. Collins, C. B. G. Bottoli, Hydrophylic interaction chromatography, Trends in Anal. Chem. 37 (2012) 48-60

10. M.A.Strege, S. Stevensen, S. M.Lawrence, Mixed-mode anion-cation exchange/hydrophilic interaction liquid chromatography-electrospray mass spectrometry as an alternative to reversed phase for small molecule drug discovery, Anal. Chem., 72 (2000) 4629-4633

11. M.A.Strege, Hydrophilic interaction chromatographyelectrospray mass spectrometry analysis of polar compounds for natural product drug discovery, Anal. Chem., 70 (1998) 2439-2445

12. B.Y. Zhu, C.T. Colin, R.S. Hodges, Hydrophilicinteraction chromatography of peptides on hydrophilic and strong cation-exchange columns, J. Chromatogr., 548 (1991) 13-24.

13. T. Saga, Y. Inoue, K. Yamaguchi, Determination of carbohydrates by hydrophilic interaction chromatography with pulsed amperometric detection using postcolumn $\mathrm{pH}$ adjustment, J. Chromatogr. A, 625 (1992) 151-155.

14. Q. W. Yu, B. Lin, Y. Q. Feng, F. P. Zou, Application of humic acid bonded silica as a hydrophilic interaction chromatographic stationary Phase in separation of polar compounds, J. Liq. Chromatogr. Related. Technol., 31 (2008) 64-78.

15. X. Liu, C. Pohl, New hydrophilic interaction/ reversed-phase mixed-mode stationary phase and its application for analysis of nonionic ethoxylated surfactants, J. Chromatogr. A, 1191 (2008) 83-89.

16. H. Hinterwirth, M. Lammerhofer, B. Preinerstorfer, A. Gargano, R. Reischl, W. Bicker, et al., Selectivity issues in targeted metabolomics: separation of phosphorylated carbohydrate isomers by mixedmode hydrophilic interaction/ weak anion exchange chromatography, J. Sep. Sci., 33 (2010) 3273-3282.

17. X. Liu, C.A. Pohl, HILIC behavior of a reversed-phase/ cation-exchange/anionexchange trimode column, J. Sep. Sci., 33 (2010) 779-786.

18. X. Liu, C.A. Pohl, Comparison of reversed-phase/ cation-exchange/anion-exchange trimodal stationary phases and their use in active pharmaceutical ingredient and counterion determinations, J. Chromatogr. A, 1232 (2012) 190-195.

19. X. Liu, C. Pohl, A. Woodruff, J. Chen, Chromatographic evaluation of reversedphase/anion-exchange/cationexchange trimodal stationary phases prepared by electrostatically driven self-assembly process, J. Chromatogr. A, 1218 (2011) 3407-3412.

20. Y. Zhao, H.C. Law, Z. Zhang, H.C. Lam, Q. Quan, G. $\mathrm{Li}$, et al., Online coupling of hydrophilic interaction/ strong cation exchange/reversed-phase liquid chromatography with porous graphitic carbon liquid chromatography for simultaneous proteomics and $\mathrm{N}$-glycomics analysis, J. Chromatogr. A, 1415 (2015) 57-66.

21. A.S. Feste, I.Khan, Separation of glucooligosaccharides and polysaccharide hydrolysates by gradient elution hydrophilic interaction chromatography with pulsed amperometric detection, J. Chromatogr., 630 (1992) 129-139. 
22. S.C. Churms, Recent progress in carbohydrate separation by high-performance liquid chromatography based on hydrophilic interaction, J. Chromatogr. A, 720 (1996) 75-91.

23. S.C. Lin, W.C. Lee, Separation of a fructooligosaccharide mixture by hydrophilic interaction chromatography using silica-based micropellicular sorbents, J. Chromatogr. A, 803 (1998) 302-306.

24. A.R. Oyler, B.L. Armstrong, J.Y. Cha, M.X. Zhou, Q. Yang, R.I. Robinson, R. Dunphy, D.J. Burinsky, Hydrophilic interaction chromatography on aminosilica phases complements reversed-phase high performance liquid chromatography and capillary electrophoresis for peptide analysis, J. Chromatogr. A, 724 (1996) 378-383.

25. T. Yoshida, Peptide separation in normal phase liquid chromatography, Anal. Chem., 69 (1997) 3038-3043.

26. C.T. Mant, L.H. Kondejewski, R.S. Hodges, Hydrophilic interaction/cation-exchange chromatography for separation of cyclic peptides, J. Chromatogr. A, 816 (1998) 79-88.

27. T. Yoshida, T. Okada, T. Hobo, R. Chiba, Calculation of amino acid hydrophilicity indices for retention of peptides on amide, diol and silica columns in normalphase liquid chromatography, Chromatographia, 52 (2000) 418-424.

28. Y. Guo, S. Gaiki, Retention behavior of small polar compounds on polar stationary phases in hydrophilic interaction chromatography, J. Chromatogr. A, 1074 (2005) $71-80$

29. Y. Kawachi, T. Ikeami, H. Takubo, Y. Ikeami, M. Miyamoto, N. Tanaka, J. Chromatogr. A, 1218 (2011) 5903-5919.

30. X. Qiao, L. Zhang, N. Zhang, X. Wang, X. Qin, H. Yan, et al., Imidazolium embedded C8 based stationary phase for simultaneous reversed-phase/hydrophilic interaction mixed-mode chromatography, J. Chromatogr. A, 1400 (2015) 107-116.

31. M. Sun, J. Feng, C. Luo, X. Liu, S. Jiang, Benzimidazole modified silica as a novel reversed-phase and anionexchange mixed-mode stationary phase for HPLC, Talanta, 105 (2013) 135-141.

32. K. HU, W. Zhang, H. Yang, Y. Cui, J. Zhang, W. Zhao, A. Yu, S. Zhang, Calixarene ionic luqiuid modified silica gel: A novel stationary phase for mixed-mode chromatography, Talanta, 152 (2016) 392-400.

33. H. Aral, T. Aral, K.S. Çelik, G. Topal, Preparation of a novel ionic hybdid stationary phase by non-covalent functionalization of single-walled carbon nanotubes with amino-derivatized silica gel for fast HPLC separation of aromatic compounds, Talanta, 149 (2016) 21-29.

34. T. Aral, H. Aral, B. Ziyadanoğulları, R. Ziyadanoğulları, Synthesis of a mixed-model stationary phase derived from glutamine for HPLC separation of structurally different biologically active compounds: HILIC and reversed-phase applications, Talanta, 131 (2015) 6473.

35. H. Aral, T.Aral, B. Ziyadanoğulları, R. Ziyadanoğulları, Development of a novel amide-silica stationary phase for the reversed-phase HPLC separation of different classes of phytohormones, Talanta, 116 (2013) 155-163.
36. Q. Wang, Y. Long, L. Yao, L. Xu, Z.G. Shi, L. Xu, Preparation, characterization and application of a reversed phase liquid chromatography/hydrophilic interaction chromatography mixed-mode C18-DDT stationary phase, Talanta, 146 (2016) 442-451.

37. D. Kotani, I. D'Acquarica, A. Ciogli, C. Villani, D. Capitani, J. Chromatogr. A, 1232 (2012) 196-211.

38. Y. Li, Y. Feng, T. Chen, H. Zhang, Imidazoline type stationary phase for hydrophilic interaction chromatography and reversed-phase liquid chromatography, J. Chromatogr. A, 1218 (2011) 59875994.

39. S. Liu, H. Xu, J. Yu, D. Li, M. Li, X. Qiao, et al., Novel imidazolium-embedded N,N-dimethylaminopropylfunctionalized silica-based stationary phase for hydrophilic interaction/reversed-phase mixed-mode chromatography, Anal. Bioanal. Chem., 407 (2015) 8989-8997.

40. X.D. Cheng, X.T. Peng, Q.W. Yu, B.F. Yuan, Y.Q. Feng, Preparation and chromatographic evaluation of a novel phosphate ester-bonded stationary phase with complexation and hydrophobic interactions retention mechanism, J. Chromatogr. A, 1302 (2013) 81-87.

41. Y. Zhang, Y. Zhang, G. Wang, W. Chen, P. He, Q. Wang, Simultaneous separation of polar and non-polar mixtures by capillary HPLC based on an ostadecylsilane and taurine derivatized silica continuously packed column, Talanta, 161 (2016) 762768.

42. Q. Wang, M. Ye, L. Xu, Z.G. Shi, A reversed-phase/ hydrophilic interaction mixed-mode C18-Diol stationary phase for multiple applications, Anal. Chim. Acta, 888 (2015) 182-190.

43. T. Liang, Q. Fu, A. Shen, H. Wang, Y. Jin, H. Xin, Y. Ke, Z. Guo, X. Liang, Preparation and chromatographic evaluation of newly designed steviol glycoside modified-silica stationary phase in hydrophilic interaction liquid chromatography and reversed phase liquid chromatography, J. Chromatogr. A, 1388 (2015) 110-118.

44. H. Qui, M. Zhang, T. Gu, M. Takafuji, H. Ihara, A Sulphonic-azobenzene-grafted silica amphiphilic material: a versatile stationary phase for mixed-mode chromatography, Chem. Eur. J., 19 (2013) 1800418010.

45. S. Bocian, A. Nowaczyk, B. Buszewski, New-alkylphospate bonded stationary phase for liquid chromatographic separation of biologically active compounds, Anal. Bioanal. Chem., 404 (2012) 731-740.

46. Z. Liu, B.D. Cai, Y.Q. Feng, Rapid determination of endogenous cytokinins in plant samples by combination of magnetic solid phase extraction with hydrophilic interaction chromatography-tandem mass spectrometry, J. Chromatogr. B, 891-892 (2012) 27-35.

47. T. Tang, W.B. Zhang, J.W. Xu, M. Z. Xia, X.D. Gong, F.Y. Wang, T. Li, Synthesis, characterization, and application of a novel multifunctional stationary phase for hydrophilic interaction/reversed phase mixed-mode chromatography, Chinese J. Anal. Chem., 45 (2017) 56-60. 
48. L. Qiao, A. Duou, X. Shi, H. Li, Y. Shan, X. Lu, G. Xu, Development and evaluation of new imidazoliumbased zwitterionic stationary phases for hydrophilic interaction chromatography, J. Chromatogr. A, 1286 (2013) 137-145.

49. L. Qiao, X. Zhou, Y. Zhang, A. Yu, K. Hu, S. Zhang, 4-Chloro-6-pyrimidinylferrocene modified silica gel: A novel multiple-function stationary phase for mixedmode chromatography, Talanta, 153 (2016) 8-16.
50. A. Shen, X. Li, X. Dong, J. wei, Z. Guo, X. Liang, Glutathione-based zwitterionic stationary phase for hydrophilic interaction/cation-exchange mixed-mode chromatography, J. Chromatogr. A, 1314 (2013) 63-69. 